\title{
Thermogenesis in Diabetes-Obesity Syndromes in Mutant Mice
}

\author{
D. L. Coleman \\ The Jackson Laboratory, Bar Harbor, Maine, USA
}

Summary. The two mouse mutants, obese (ob) and diabetes $(d b)$, cause similar diabetes-obesity syndromes that are characterized by a marked increase in apparent metabolic efficiency with regard to utilization of energy. A failure to thermoregulate in a normal fashion would save energy which could then be diverted to other functions and be reflected as increased metabolic efficiency. This study assesses the contribution of a defect in thermogenesis to the increased metabolic efficiency. Thermogenesis in obese $(o b)$ and diabetes $(\mathrm{db})$ mutant mice was quantified at various environmental temperatures. Both mutants maintained body temperatures near normal when maintained at ambient temperatures $\left(23^{\circ} \mathrm{C}\right)$, and if exposed to cold at $10^{\circ} \mathrm{C}$ for a brief period, became cold-adapted and would survive indefinitely at $4^{\circ} \mathrm{C}$. Rectal temperatures of mutants maintained at $4^{\circ} \mathrm{C}$ were only $1^{\circ}-2^{\circ} \mathrm{C}$ less than those seen in normal mice. This maintenance of nearly normal body temperature at temperatures less than thermoneutral was reflected by increased food consumption in all mice maintained in the cold. The data presented suggest that the defect in thermogenesis in both mutants is not a major cause of the increased metabolic efficiency. Hyperinsulinaemia, a consistent feature of both mutants, might by increasing anabolic processes (synthesis) and decreasing degradation spare energy normally used for tissue turnover and account for some of this increased metabolic efficiency.

Key words: Metabolic efficiency, obesity, $o b / o b$ mice, $d b / d b$ mice, non-shivering thermogenesis, cold adaptation.

The recessive mutations in the mouse, 'obese' $(o b)$ and 'diabetes' $(d b)$, have been used extensively in studies involving perturbations in energy balance associated with obesity. Both mutants have the ability to become obese even when calories are severely restricted [1-5], gaining normal amounts of weight while depositing abnormal amounts of fat even when restricted to $66 \%$ of the amount of food eaten by normal mice [6]. Several mechanisms have been proposed to explain this remarkable increase in metabolic efficiency. A major saving of energy in both the obese and diabetes mutants has been suggested to result from a defect in thermoregulatory thermogenesis [7-9]. At ambient environmental temperatures, the body temperature of the mutants remains lower than normal, and when exposed to the cold $\left(4^{\circ} \mathrm{C}\right)$, the obese mutants rapidly become hypothermic and die within a few hours [8-10]. An observed increased metabolic rate in obese mice adapted to $10^{\circ} \mathrm{C}$ suggests that the defect in thermoregulatory thermogenesis is only partial [7]. Even so, a defect in cold-induced non-shivering thermogenesis (that is, a defect in the increase of heat production normally induced by cold but not due to the physical activity of shivering) has been suggested as the major defect contributing to the increased efficiency. Thus when pair-fed that amount of food eaten by normal mice, these mutants can still gain excess weight and deposit excess adipose tissue owing to the diversion of energy utilization from thermogenesis to lipogenesis. Recent studies have established that the obese mouse fails to increase binding sites for purine nucleotides on the mitochondria of brown adipose tissue in response to cold exposure $[11,12]$. Such increased binding capacity normally correlates with increased thermogenic capacity.

As well as a defect in thermogenesis, obese and diabetes mutants have a lower basal activity of $\mathrm{Na}^{+}, \mathrm{K}^{+}$-ATPase which is not induced in response to thyroid hormone as it is in normal mice [13, 14]. $\mathrm{Na}^{+}, \mathrm{K}^{+}$-ATPase is a membrane protein involved in ion flux which, when cycling rapidly, utilizes consid- 
erable energy in the form of ATP and produces heat. This process operating in muscle has been suggested as a possible source of heat for the maintenance of body temperature [13]. If this is so, a reduced activity of the enzyme could perhaps explain the lower metabolic rate in mutants. Recent evidence, however, suggests that the operation of this ATPase probably does not contribute significantly to body heat produced by non-shivering thermogenesis, which occurs primarily in the brown adipose tissue $[15,16]$.

The normal metabolism of most organisms involves considerable energy wastage in other types of energy-consuming cycles such as the continuous degradation and re-synthesis of protein, and the breakdown of triglycerides to non-esterified fatty acids and their re-esterification again to triglycerides. These metabolic energy consuming cycles are under the control of several hormones, especially insulin. The extreme hyperinsulinaemia typical of these obesity mutants might provide an environment very favourable for anabolic processes and unfavourable for degradation, thereby inhibiting metabolic turnover and producing a potential substantial saving of energy which could be reflected in increased metabolic efficiency, increased fat stores, or both.

My studies [2,6] with obese and diabetes mice have confirmed the increased metabolic efficiencies observed by others $[1,3-5]$ and have demonstrated that obese mutants can gain weight and deposit excess fat when fed an amount of food only $50 \%$ of that eaten by normal mice. When subjected to a total fast mutants utilize their energy reserves more efficiently, prolonging survival and permitting the total utilization of their tissue reserves $[2,6]$. In attempts to quantify any differences in metabolic processes that contribute to the increased efficiency, I have measured food intake, weight gain, and energy utilization under various conditions of food restriction and at various environmental temperatures.

\section{Materials and Methods}

Normal and obese $(o b)$ mice of the C57BL/6J (BL/6) strain were obtained from the animal Resources Department of the Jackson Laboratory. Normal and diabetes $(d b)$ mice of either the $\mathrm{BL} / 6$ or $\mathrm{C} 57 \mathrm{BL} / \mathrm{KsJ}(\mathrm{BL} / \mathrm{Ks})$ strain were produced in our research colony. The mice used in these studies were all males. In those experiments investigating the ability of dietary restriction to modify the severity of diabetes, mutants of the $\mathrm{BL} / \mathrm{Ks}$ strain were used since they normally develop severe diabetes; otherwise the BL/6 strain was used. All mice were maintained on commercial mouse chow (Emory Morse, Guilford, Connecticut) containing $19 \%$ protein and $6 \%$ fat. The mice housed in operant boxes were fed mouse Noyes Type $M$ pellets by dispenser. These pellets weighed $20 \mathrm{mg}$ and consisted of $63 \%$ carbohydrate, $24 \%$ protein and $5 \%$ fat fortified with vitamins and minerals.
Except in the operant experiments, food consumption was measured by providing mice with a weighed amount of food each morning and subtracting the amount left after each $24-\mathrm{h}$ period. These mice were housed individually, either at $23^{\circ} \mathrm{C}$ or in thermostatically controlled environmental boxes at different temperatures. The mice used in the feeding experiments at $4^{\circ} \mathrm{C}$ were exposed to $10^{\circ} \mathrm{C}$ for a $1-2$ week period of acclimatization before maintenance at $4^{\circ} \mathrm{C}$. Food consumption, weight gains, blood glucose concentrations and body temperature were followed over an additional 2-week period at all environmental temperatures. Colonic temperature was determined with a rapidly responding thermister probe coupled to a telethermometer (Yellow Springs, Ohio, Model $42 \mathrm{SE}$ ). The thermocouple was inserted $2 \mathrm{~cm}$ into the rectum and maintained there until body temperature remained constant (usually 30s). Body composition was determined by extracting the carcasses with acetone for $72 \mathrm{~h}$ using a Soxlet apparatus. The dried carcass was weighed to obtain the fat-free dry weight. Water was removed from the extracted lipid by evaporation in an oven $\left(110^{\circ} \mathrm{C}\right)$ for $48-72 \mathrm{~h}$. The lipid extract remaining was weighed and expressed as percentage of live body weight. Non-esterified fatty acids were determined according to the procedure of Itaya und Ui [17]. Blood glucose concentration was determined by a standard colorimetric procedure [18].

In those studies involving pair-feeding, a normal mouse was trained to press a bar to obtain its food. This system was yoked to food dispensers in other cages in which mutants were housed. Mutants obtained their food by the schedule determined by the normal operant mouse. The number of bar presses per day recorded on a counter was used to determine the total food consumption. Spillage as evidenced by dropped pellets was trivial, and was not corrected for. The schedule of pellet delivery could be regulated to give mutants any percentage of the food presented to the normal mouse ( $66 \%$ and $50 \%$ in these studies). Pair-feeding was carried out at ambient temperature except for studies designed to assess whether the amount of food consumed at thermoneutral temperature $\left(33^{\circ} \mathrm{C}\right)$ was sufficient to sustain obese mutants but not enough to produce obesity. In these studies the normal mouse operating the lever was housed in an environmental chamber maintained at $33^{\circ} \mathrm{C}$. The mutant mice yoked to this system were housed at ambient temperature $\left(23^{\circ} \mathrm{C}\right)$.

\section{Results}

\section{Pair-Feeding Experiments}

The results of the pair-feeding experiments are shown in Table 1. It had been shown previously that obese and diabetes mice pair-fed that amount of food eaten by normal mice on the same schedule still gained an additional $1-2 \mathrm{~g}$ more weight than did normal mice in a 4-week period [2]. Further, most of the increased weight gain was in increased lipid stores as established by body composition analysis. Similar data based on only 2 weeks of pair-feeding are shown in Table 1 for the purpose of comparing these original values with those found using the more restricted regimens (two-thirds and half normal food intake on the same feeding schedule). When diabetes mice were restricted to two-thirds the food intake of normal, the results were very similar to those of pair-feeding (Table 1, line 4 versus line 3). Again the excess weight 
Table 1. Body weight and body fat on various feeding schedules in normal and mutant mice

\begin{tabular}{|c|c|c|c|c|c|c|}
\hline \multicolumn{2}{|c|}{ Genotype } & \multirow[t]{2}{*}{ Starting weight (g) } & \multicolumn{2}{|c|}{ Weight after 2 weeks (g) } & \multicolumn{2}{|l|}{ Fat $(\%)^{\mathrm{b}}$} \\
\hline & & & Fed ad libitum & Pair-fed & Ad libitum & Pair-fed \\
\hline 1 & $\mathrm{BL} / \mathrm{Ks}+/+$ & $14.9 \pm 0.25$ & $20.0 \pm 0.57(5.1)^{a}$ & $18.7 \pm 0.41(3.8)$ & $16.1 \pm 1.1$ & $14.9 \pm 0.83$ \\
\hline 2 & $\mathrm{BL} / \mathrm{Ks} o b / o b$ & $17.0 \pm 0.32$ & $28.6 \pm 0.93(11.6)$ & $21.6 \pm 0.64(4.6)$ & $40.3 \pm 0.92$ & $40.7 \pm 0.90$ \\
\hline 3 & $\mathrm{BL} / \mathrm{Ks} d b / d b$ & $16.8 \pm 0.36$ & $27.6 \pm 1.21(10.8)$ & $21.3 \pm 1.32(4.5)$ & $38.8 \pm 1.0$ & $38.7 \pm 0.85$ \\
\hline 4 & $\mathrm{BL} / \mathrm{Ks} d b / d b$ & $15.3 \pm 0.43$ & - & $19.5 \pm 0.61(4.2)$ & - & $47.4 \pm 1.60$ \\
\hline 5 & $\mathrm{BL} / \mathrm{Ks} d b / d b^{d}$ & $15.8 \pm 0.33$ & - & $18.7 \pm 0.75(2.9)$ & - & $37.0 \pm 1.21$ \\
\hline 6 & $\mathrm{BL} / 6+/+$ & $19.5 \pm 0.47$ & - & $21.5 \pm 0.82(2.0)$ & - & $17.7 \pm 0.58$ \\
\hline 7 & $\mathrm{BL} / 6 \circ b / a b$ & $20.6 \pm 0.65$ & - & $23.6 \pm 0.95(3.0)$ & - & $40.0 \pm 0.91$ \\
\hline 8 & $\mathrm{BL} / 6 d b / d b$ & $18.8 \pm 0.53$ & - & $22.2 \pm 0.73(3.4)$ & - & $38.4 \pm 0.83$ \\
\hline
\end{tabular}

Figures represent average values obtained from four male mice in each group maintained at $23^{\circ} \mathrm{C}$ except for data presented in lines $6-8$ in which the mutants maintained at $23^{\circ} \mathrm{C}$ were pair-fed with normal mice maintained at thermoneutrality $\left(33^{\circ} \mathrm{C}\right)$ daily. Food intake averaged $240-280$ pellets in normal mice maintained at $23^{\circ} \mathrm{C}$ and was reduced to $150-190$ pellets in the mice maintained at $33^{\circ} \mathrm{C}$.

a Weight gains in $\mathrm{g} / 2$ week period are in parentheses.

b The percentage body fat in young mutants of age similar to that of the mutants fed ad libitum at the start of the experiment, ranged from $23 \%$ to $30 \%$ in four obese and four diabetes mutants.

c Fed two-thirds the amount of food eaten by normal mice on same schedule.

${ }^{d}$ Fed half the amount of food eaten by normal mice on same schedule

gain was reflected in increased total fat in the mutants. When the diabetes mice were maintained on $50 \%$ of normal food intake they still made a significant weight gain in the 2-week period, $2.9 \mathrm{~g}$ (line 5) compared with $3.8 \mathrm{~g}$ (line 1) for the normal operant control mice fed ad libitum under operant conditions or $4.5 \mathrm{~g}$ (line 3) for the pair-fed mutant. Again the percentage body fat indicated the maintenance of obesity in spite of markedly reduced food intake. Pair-feeding at 50\% of the normal amount was continued for up to 6 months with $\mathrm{BL} / \mathrm{Ks}-d b / d b$ mutants in order to assess the effects of limited food on the course of the diabetes as well as on the development of obesity. After 2 months on this regimen the average weight gain of six mutants was $6.5 \mathrm{~g}$ compared with a gain of $8.0 \mathrm{~g}$ for the three control mice fed ad libitum. Blood glucose concentration of the mutants was elevated slightly (10.0 versus $6.7 \mathrm{mmol} / \mathrm{l}$ ) at the start of the $50 \%$ feeding, but rose gradually to over $16 \mathrm{mmol} / 1$ by 2 months. The blood glucose concentrations of mutants remained elevated for the duration of the study. Water intake increased from $4 \mathrm{ml} /$ day to an average of $12 \mathrm{ml} /$ day after 2 months of restricted feeding. The urine contained significant amounts of glucose. Two mutants died before the end of the experiment. The average weight gain of the four survivors was $8.8 \mathrm{~g}$ compared with $12.4 \mathrm{~g}$ for the controls fed ad libitum. Plasma immunoreactive insulin concentrations were $80-250$ $\mathrm{mU} / 1$ at sacrifice compared with $20-30 \mathrm{mU} / 1$ for the controls. The percentage carcass lipid ranged from $30 \%$ to $35 \%$ compared with $15 \%$ to $20 \%$ for normal mice. Histology of the pancreas revealed marked $B$ cell degranulation with signs of degenerative changes and islet atrophy typical of that seen with either obese or diabetes mice maintained on the $\mathrm{BL} / \mathrm{Ks}$ background and fed ad libitum.

When mutants were pair-fed with normal mice maintained at thermoneutrality $\left(33^{\circ} \mathrm{C}\right)$, daily food intake averaged 17520 -mg pellets $(62 \%$ of the amount consumed at $23^{\circ} \mathrm{C}$ ). Under these conditions the mutants should get exactly the amount of food required for maintenance, less that normally required for heat production. If a defect in thermogenesis were a major factor in the remarkable metabolic efficiency of the mutants, then they should maintain body weights similar, if not identical, to those of control mice pairfed at thermoneutrality. On the contrary, the $o b / o b$ and $d b / d b$ mice still gained 3.0 and $3.4 \mathrm{~g}$ respectively, compared with $2.0 \mathrm{~g}$ for the normal control animals (Table 1, lines 7 and 8 versus line 6). Body compositions remained obese (38-40.4\% fat) compared with normal (15\% fat).

\section{Food Consumption at Various Environmental Temperatures}

Both obese and diabetes mutants ate significantly more food than normal mice at all environmental temperatures studied (Fig. 1). Food consumption decreased by $40 \%$ in both mutant and control mice when the temperature was raised from $23^{\circ} \mathrm{C}$ to $33^{\circ} \mathrm{C}$ (thermoneutral temperature for the mouse). Decreasing the ambient temperature produced consistent increments in the amount of food consumed in normal mice. Although the obese mutants also increased food consumption, they did not do so as much as normal 


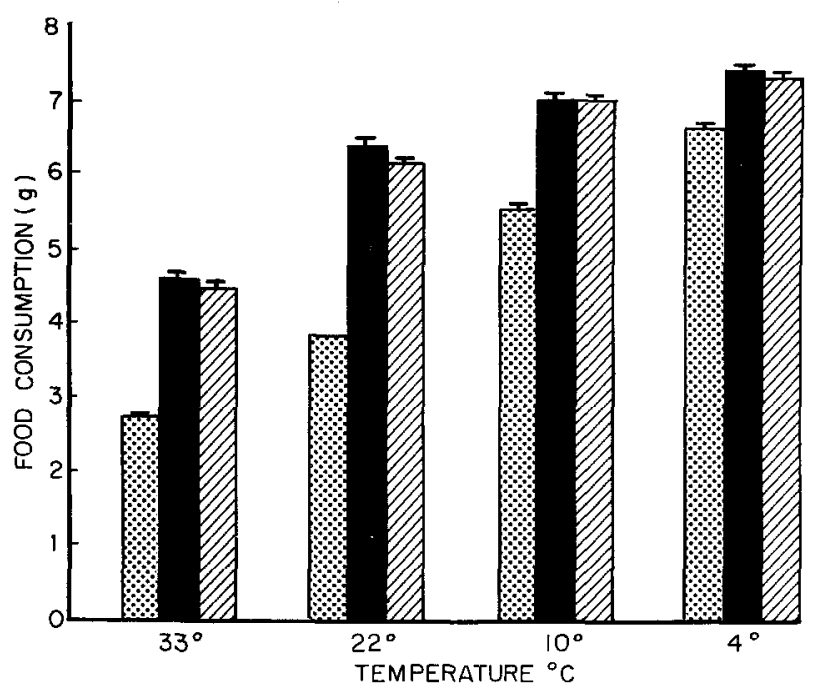

Fig. 1. Food consumption of normal and mutant mice maintained at different environmental temperatures. Data were obtained on 12 mice of each genotype at each temperature during a 2-week period. No significant differences were found between obese and diabetes mice. Mutants ate significantly more food at all temperatures than controls $(p<0.01)$. Each decrease in the environmental temperature produced significant increases in food consumption in each

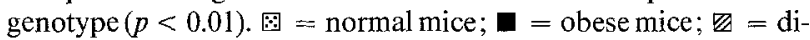
abetes mice

Table 2. Effect of environmental temperature on body temperature in normal and mutant mice

\begin{tabular}{llll}
\hline $\begin{array}{l}\text { Environmental } \\
\text { temperature }\end{array}$ & Genotype & & \\
\cline { 2 - 4 } & $+/+$ & $d b / d b$ & $o b / o b$ \\
\hline $23^{\circ} \mathrm{C}$ & $36.8 \pm 0.23$ & $36.3 \pm 0.15$ & $35.5 \pm 0.20$ \\
$10^{\circ} \mathrm{C}$ & $35.1 \pm 0.48$ & $35.1 \pm 0.16^{\mathrm{a}}$ & $35.2 \pm 0.22^{\mathrm{a}}$ \\
$4^{\circ} \mathrm{C}$ & $36.5 \pm 0.22$ & $35.6 \pm 0.16^{\mathrm{a}}$ & $34.2 \pm 0.39^{\mathrm{a}, \mathrm{b}}$ \\
\hline
\end{tabular}

Results represent body temperature $\left({ }^{\circ} \mathrm{C}\right)$

Average values \pm SEM were obtained on at least 10 mice of each genotype maintained for 1 week at each environmental temperature.

a Significantly different from the same genotype maintained at $23^{\circ} \mathrm{C}(p<0.01$, Student's ' $t$ ' test $)$.

${ }^{b}$ Significantly different from all other groups $(p<0.01$, Student's 't' test) mice. At $23^{\circ} \mathrm{C}$, the mutants were eating $60 \%$ more food than normal mice, while at $4^{\circ} \mathrm{C}$ the mutants were only eating $10 \%$ more food than normal mice. Daily food intake at $4^{\circ} \mathrm{C}$ was $7.0 \mathrm{~g}$ for normal mice and $7.5 \mathrm{~g}$ for mutants.

\section{Maintenance of Body Temperature}

At ambient temperature, the rectal temperatures of mutants were slightly lower than normal mice (Table 2 , line 1) but the differences were not significant. Rectal temperatures of normal mice, adapted to $10^{\circ} \mathrm{C}$ and $4^{\circ} \mathrm{C}$, were not significantly different from those of normal mice maintained at $23^{\circ} \mathrm{C}$. The body temperatures of normal mice dropped to a nadir of about $32^{\circ} \mathrm{C}$ in the initial few hours of cold exposure and then rose to normal again by $24-36 \mathrm{~h}$. In contrast, obese and diabetes mice were unable to withstand the sudden shift from $23^{\circ} \mathrm{C}$ to $4^{\circ} \mathrm{C}$. Rectal temperatures dropped to below $30^{\circ} \mathrm{C}$ and most mutants (six out of ten obese and four of ten diabetes mice) died before $24 \mathrm{~h}$. Some of the survivors died during the next 2 days but a few did adapt and survived. In order to increase the survival rates, we lowered the ambient temperature in two steps, to $10^{\circ} \mathrm{C}$ for 2 weeks before decreasing to $4^{\circ} \mathrm{C}$. Most mutant mice survived this regimen. Subsequent experiments revealed that cold acclimatization for as little as 1 or 2 days was sufficient to allow survival at $4^{\circ} \mathrm{C}$. Body temperatures of both obese and diabetes mice maintained at $10^{\circ} \mathrm{C}$ were significantly lower than those seen in mice of all genotypes maintained at $23^{\circ} \mathrm{C}$. Decreasing the temperature to $4{ }^{\circ} \mathrm{C}$ had no further effect on the body temperatures of either normal or diabetes mice, but did lower the body temperature of obese mice to values significantly lower than those seen in all other mice maintained at either $10^{\circ} \mathrm{C}$ or $23^{\circ} \mathrm{C}$.

\section{Physiological Changes on Cold Adaptation}

Both the obese and diabetes mice had elevated blood glucose concentrations before being placed in the cold (Table 3 ). The obese mice were significantly

Table 3. Effect of cold exposure on blood glucose and plasma non-esterified fatty acid (NEFA) concentrations in normal and mutant mice

\begin{tabular}{|c|c|c|c|c|c|}
\hline \multirow[t]{2}{*}{ Genotype } & \multicolumn{2}{|l|}{ Kept at $23^{\circ} \mathrm{C}$} & \multirow{2}{*}{$\begin{array}{l}4 \mathrm{~h} \text { at } 4^{\circ} \mathrm{C} \\
\mathrm{NEFA} \\
(\mathrm{mmol} / \mathrm{l})\end{array}$} & \multicolumn{2}{|l|}{1 week at $4^{\circ} \mathrm{C}$} \\
\hline & $\begin{array}{l}\text { Blood glucose } \\
(\mathrm{mmol} / 1)\end{array}$ & $\begin{array}{l}\text { NEFA } \\
(\mathrm{mmol} / \mathrm{l})\end{array}$ & & \multicolumn{2}{|c|}{ Blood glucose $(\mathrm{mmol} / \mathrm{l})$} \\
\hline$+1+$ & $7.0 \pm 0.14$ & $0.587 \pm 0.054$ & $0.839 \pm 0.049^{\mathrm{a}}$ & $127.8 \pm 7.2$ & $128.5 \pm 2.8$ \\
\hline$d b / d b$ & $10.6 \pm 1.27$ & $0.719 \pm 0.052$ & $0.861 \pm 0.062$ & $209.1 \pm 19.7$ & $221.8 \pm 17.5$ \\
\hline$a b / o b$ & $14.9 \pm 1.01$ & $0.671 \pm 0.10$ & $0.963 \pm 0.096^{\mathrm{a}}$ & $322.5 \pm 44.6$ & $319.0 \pm 8.0$ \\
\hline
\end{tabular}

Results represent mean \pm SEM in six mice of each genotype. All mice were maintained at ambient temperature before cold exposure. Mutant mice in the 1 or 2 -week studies at $4^{\circ} \mathrm{C}$ were cold acclimatized at $10^{\circ} \mathrm{C}$ for $48 \mathrm{~h}$.

a Significantly different from ambient ( $p<0.01$, Student's ' $t$ ' test) 
more hyperglycaemic before cold adaptation and the hyperglycaemia remained significantly elevated compared with either diabetes or normal mice during the 2-week period in the cold. This degree of hyperglycaemia in the cold-adapted obese mice was greater than one would expect during normal development at $23^{\circ} \mathrm{C}$. Diabetes mice made more modest increases in the blood glucose concentrations during the cold exposure, similar to that expected during normal development at $23^{\circ} \mathrm{C}$. Normal mice remained euglycaemic throughout the entire period.

Non-esterified fatty acid concentrations rose significantly in normal mice exposed for $4 \mathrm{~h}$ to $4{ }^{\circ} \mathrm{C}$. The already elevated concentrations in mutants also increased on cold exposure although the increase was significant only in the obese mutant (Table 3 ).

Body-weight gain in all mice maintained at $4{ }^{\circ} \mathrm{C}$ was somewhat less than that seen at room temperature. Weight gain per week in four groups of five normal mice ranged from 0.35 to $1.68 \mathrm{~g}$ with an average gain of $1.11 \mathrm{~g}$. A typical gain in normal mice raised at room temperature at this age would be $2-3 \mathrm{~g}$. Weight gain for the diabetes mutants ranged from 1.8 to $3.75 \mathrm{~g}$ with an average gain of $2.5 \mathrm{~g} /$ week. Weight gain by the obese mice seemed slightly greater ranging from 1.5 to $4.3 \mathrm{~g}$ with an average gain of $3.2 \mathrm{~g} /$ week. These weight gains in mutants were much less than typical $(8-10 \mathrm{~g} /$ week $)$ at ambient temperatures. The significance of these differences in growth rate is questionable since the individual mice maintained at $4^{\circ} \mathrm{C}$ varied greatly with respect to the weight gained per week.

\section{Discussion}

The results shown in Table 1 demonstrate the remarkable efficiency by which the two obesity mutants, obese and diabetes, utilize even severely limited amounts of food to maintain normal body weight and accumulate excessive amounts of fat. Even when restricted to $50 \%$ of that amount of food eaten by normal mice, weight gain remains impressive (Table 1 , line 5) although somewhat less than that for normal mice fed ad libitum. In spite of severe food restriction, calories were still diverted to the synthesis of fat (a highly energy-consuming process), growth and survival were sustained over a $4-6$ month period, and the typical development of the diabetes-like syndrome occurred. Blood glucose concentrations increased, urinary output increased dramatically; glycosuria became severe and at autopsy typical degenerative changes in the islets of Langerhans were observed. These data show that hyperphagia is not a necessary prerequisite to either obesity or diabetes, although it is a major factor exacerbating the severity of both conditions. The food-restricted mutant mice in these pair- feeding experiments remained healthy and very active during the entire study, spending most of the day pacing the cage in anticipation of the appearance of the next pellet of food in the dispenser. In contrast, the normal operant mouse lay quietly in his cage and moved about the cage only to dispense food or to get water. Decreased energy expenditure because of lack of exercise in the mutants did not appear to be a factor in the increased metabolic efficiency observed.

If a failure of thermogenesis in mutants were solely responsible for their increased metabolic efficien$c y$, then pair-feeding with normal mice maintained at thermoneutrality should provide exactly the amount of food required for normal maintenance since in these conditions the normal mouse would not have to consume increased amounts of energy for thermogenesis and the mutants would be presented with only sufficient food for maintenance exclusive of that amount used by normals for thermoregulation. Pairfeeding of obese mutants at $23^{\circ} \mathrm{C}$ to normal mice maintained at thermoneutrality $\left(33^{\circ} \mathrm{C}\right)$ still produced a greater weight gain after 2 weeks ( 3.0 to $3.4 \mathrm{~g}$ ) in mutants than that seen in normal mice $(2.0 \mathrm{~g}$, Table 1 , lines 6-8). This observation demonstrates that even when deprived of the specific amount of food required by a normal mouse for thermogenesis, the food deficit is not sufficient to prevent increased weight gains in mutants. The mutants, housed at $23^{\circ} \mathrm{C}$, not at $33^{\circ} \mathrm{C}$ like the normal mice, probably had to expend some calories to maintain normal body temperature. Therefore, one would expect the weight gain in the obese mutants to have been even more if they, like normal mice, had been maintained at $33^{\circ} \mathrm{C}$. These data suggest that any defect in thermogenesis in mutants makes only a minor contribution to increased metabolic efficiency.

The data on food consumption of normal and both mutant mice raised at different environmental temperatures (Fig. 1) are consistent with the studies on weight gain and fat deposition seen in mutants pair-fed at thermoneutrality. At $33^{\circ} \mathrm{C}$ normal mice decreased food consumption to $60 \%$ of that eaten at $23^{\circ} \mathrm{C}$. This suggests that $40 \%$ of the food eaten at $23^{\circ} \mathrm{C}$ is used in thermogenesis and $60 \%$ is sufficient to meet other energy requirements. This same amount of food $(60 \%)$ should be the optimal amount required to sustain mutants adequately, assuming they require no energy for thermogenesis even when maintained at temperatures below thermoneutrality. In the pairfeeding studies, maintenance of obese mutants at $66 \%$ of normal food intake still permitted excess weight gain while $50 \%$ deprivation produced weight gains somewhat less than normal. These combined data support a figure of $60 \%$ of normal food intake as optimal for obesity mutants, but do not clarify the mechanisms responsible for the extra metabolic efficiency. 
These data are qualitatively similar to those of Trayhurn and Fuller [5]. However in my pair-feeding studies the mice used, although the same age, were much larger and were not in as rapid a growth phase. Consequently, the weight gains per 2 weeks in my experiments $(25 \%-30 \%)$ were not as dramatic (nearly $100 \%$ ) as found by Trayhurn and Fuller [5].

The two obese mutants and the normal mice all decreased food intake by about $40 \%$ when temperatures were increased from $23^{\circ} \mathrm{C}$ to thermoneutrality. When temperatures were decreased, all mice increased their food consumption, as would be expected, to provide energy for heat production. Both mutants exhibited identical, but insufficient, increases in food intake in response to decreases in environmental temperature when compared with normal mice (Fig. 1). At the lowest temperature $\left(4^{\circ} \mathrm{C}\right)$ both mutants ate only slightly more than did the normal mice maintained at $4^{\circ} \mathrm{C}$. This shows that mutants respond normally to increases in environmental temperature by decreasing food intake, but exhibit a blunted response when attempting to increase food intake to compensate for the increased energy required to maintain themselves at lower temperatures. This suggests either that the mutants have an improper sensing mechanism, or that the 7.0-7.5 g of the standard diet eaten at $4{ }^{\circ} \mathrm{C}$ by mice of all genotypes represents the maximum amount of food that an individual mouse can process in one day. It should be noted that mutants maintained at $4{ }^{\circ} \mathrm{C}$, unlike normal mice eating this same amount of food, failed to gain weight and even lost weight in the late stages of the study indicating that this amount of food in mutants was insufficient to meet metabolic requirements. Body composition of the cold-maintained mutants was not determined but the failure to gain weight normally, and the loss of weight in some cases suggests that the percentage lipid might have been decreased.

Our data demonstrate that although both obesity mutants have some defect in thermogenesis, they increase thermogenesis sufficiently to maintain body temperatures near normal even when maintained at $4^{\circ} \mathrm{C}$. Studies by others have shown decreased body temperatures in mutants maintained at room temperature $[7,8]$. In my studies, statistically significant decreases were not observed, although the average values were modestly decreased. The reason for this discrepancy is unknown. In our studies both mutants increased thermogenesis in response to cold. The rate of increase in body temperature was not as fast as that of normal mice but was sufficient to permit survival at $4^{\circ} \mathrm{C}$ and maintain body temperature only slightly below than that seen in normal mice. The energy utilized in maintaining body temperature in mutants would be considerable and this partial defect in thermogene- sis would not spare many calories. Even though the calories spared by the elimination of thermogenesis in mice raised at $33^{\circ} \mathrm{C}$ equate nicely with the amount of energy needed to explain the increase in the metabolic efficiency seen in mutants, other possible mechanisms as well as thermogenesis must be considered. It has been shown that brown adipose tissue mitochondria from obese mice do not increase purine nucleotide binding on exposure to the cold in a normal fashion, but they can make all other appropriate secondary responses required for survival in the cold [12]. My data suggest that the necessity for this acute adaptive response can be circumvented if cold exposure at $10^{\circ} \mathrm{C}$ for as little as $24 \mathrm{~h}$ precedes the cold adaptation at $4^{\circ} \mathrm{C}$.

The blood glucose concentration in normal mice averaged $7.0 \mathrm{mmol} / 1$ before cold exposure and did not increase during the 2 -week period (Table 3 ). Both obese mutants were mildly hyperglycaemic before cold adaptation and became increasingly hyperglycaemic on cold adaptation. The response was greatest in the obese mutant. This accumulation of glucose, not seen in normal mice, may reflect increased rates of gluconeogenesis, or an inability of the mutants to metabolize glucose sufficiently rapidly under conditions of stress, or both.

All of the obesity mutants are grossly hyperinsulinaemic. Severe hyperinsulinaemia should favour anabolic processes and promote the synthesis of body constituents while inhibiting degradation. Normal metabolism involves the continuous breakdown and synthesis of body constituents. Much energy is consumed in both synthesis and degradation. In the hyperinsulinaemic mutant the normal synthesis-degradation cycles could be directed toward synthesis and away from degradation. The saving of energy that would occur by the elimination of these types of normal metabolic futile cycles could be reflected in foodrestricted mutants as an increase in metabolic efficiency. Further, it may be that the hyperinsulinaemia of mutants is antagonistic to the actions of a variety of catabolic hormones, especially glucagon and catecholamines. Such an antagonistic action could be indirectly responsible for the lack of noradrenalineinitiated response in turning on both cold and diet-induced thermogenesis $[12,19,20]$. More critical studies in vivo are needed on the relative rates of all types of normal cycling of metabolites in both mutant and normal mice before the individual contribution of each mechanism to energy efficiency can be established.

Acknowledgements. This work was supported in part by research grants AM 14461 and AM 20725 from the National Institute of Arthritis, Metabolism and Digestive Diseases and from a grant from 
The Juvenile Diabetes Foundation. The Jackson Laboratory is fully accredited by the American Association for the Accreditation of Laboratory Animal Care. The technical assistance of Mr. R. H.Copp is gratefully acknowledged.

\section{References}

1. Alonso LC, Maren TH (1955) Effect of food restriction on body composition of hereditary obese mice. Am J Physiol 183: 284-290

2. Coleman DL (1978) Obese and diabetes: two mutant genes causing diabetes-obesity syndromes in mice. Diabetologia 14: $141-148$

3. Cox JE, Powley TL (1977) Development of obesity in mice pairfed with lean siblings. J Comp Physiol Psychol 91:347-358

4. Thurlby PL, Trayhurn P (1979) The role of thermoregulatory thermogenesis in the development of obesity in genetically obese $(o b / o b)$ mice pair-fed with lean siblings. Br J Nutr 42: $377-385$

5. Trayhurn P, Fuller L (1980) The development of obesity in genetically diabetes-obese $(d b / d b)$ mice pair-fed with lean siblings. The importance of thermoregulatory thermogenesis. Diabetologia 19: 148-153

6. Coleman DL (1981) Inherited diabetes syndromes in the mouse. In: Russell ES (ed) Progress in clinical and biological research, vol 45. The Jackson Laboratory 50th Anniversary Symposium. Alan R. Liss, New York, pp 145-158

7. Trayhurn P(1978) Thermoregulation in the diabetic-obese ( $d b /$ $d b)$ mouse: the role of nonshivering thermogenesis in energy balance. Pfluegers Arch 380:227-232

8. Trayhurn P, James WPT (1978) Thermoregulation and nonshivering thermogenesis in the genetically obese $(o b / o b)$ mouse. Pfluegers Arch 373: 189-193

9. Lin P-Y, Romsos DR, Vander Tuig JC, Leveille GA (1979) Maintenance energy requirements, energy retention and heat production in young obese $(o b / o b)$ and lean mice fed a high fat or high-carbohydrate diet. J Nutr 109: 1143-1153

10. Davis TRA, Mayer J (1954) Imperfect homeothermy in the hereditary obese hyperglycemic syndrome of mice. Am J Physiol $228: 276-283$
11. Himms-Hagen J, Desautels M (1978) A mitochondrial defect in brown adipose tissue of the obese mouse: reduced binding of purine nucleotides and a failure to respond to cold by an increase in binding. Biochem Biophys Res Commun 83: 628-634

12. Hogan S, Himms-Hagen $\mathbf{J}$ (1980) Abnormal brown adipose tissue in obese $a b / o b$ mice: response to cold. Am J Physiol 239: E301-E309

13. Bray GA, York DA, Yukimura Y (1978) Activity of $\mathrm{Na}^{+}, \mathrm{K}^{+}-$ ATPase in the liver of animals with experimental obesity. Life Sci 22: 1637-1647

14. Lin MH, Romsos DR, Akera T, Leveille GA (1978) $\mathrm{Na}^{+}, \mathrm{K}^{+}-$ ATPase enzyme units in skeletal muscle from lean and obese mice. Biochem Biophys Res Commun 80: 398-404

15. Foster DO, Frydman ML (1978) Nonshivering thermogenesis in the rat. II. Measurement of blood flow with microspheres point to brown adipose tissue as the dominant site of the calorigenesis induced by noradrenaline. Can J Physiol Pharmacol 56: $110-122$

16. Thurlby PL, Trayhurn P (1980) Regional blood flow in genetically obese $(o b / o b)$ mice. The importance of brown adipose tissue to the reduced energy expenditure on non-shivering thermogenesis. Pfluegers Archiv 385: 193-201

17. Itaya K, Ui M (1965) Colorimetric determination of free fatty acids in biological fluids. J Lipid Res 6: 16-20

18. Folin O, Malmros H (1929) Improved form of Folin's micromethod for blood sugar determinations. J Biol Chem 83: $118-120$

19. Rothwell NJ, Stock MJ (1979) A role for brown adipose tissue in diet-induced thermogenesis. Nature 281:31-35

20. Brooks SL, Rothwell NJ, Stock MJ, Goodbody AE, Trayhurn P (1980) Decreased protein conductance pathway in brown adipose tissue mitochondria of rats exhibiting dietary-induced thermogenesis. Nature 286:274-276

Received: 13 April 1981

and in revised form: 29 September 1981

Douglas L. Coleman

The Jackson Laboratory

Bar Harbor

Maine 04609, USA 